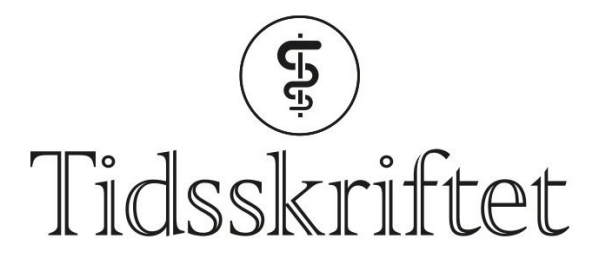

DEN NORSKE LEGEFORENING

\title{
Hurtigtest for sigdcellesykdom
}

FRA ANDRE TIDSSKRIFTER

KRISTOFFER BRODWALL

Haukeland universitetssjukehus

En hurtigtest for sigdcellesykdom hos nyfødte er et godt alternativ til ordinær screening i lavinntektsland.

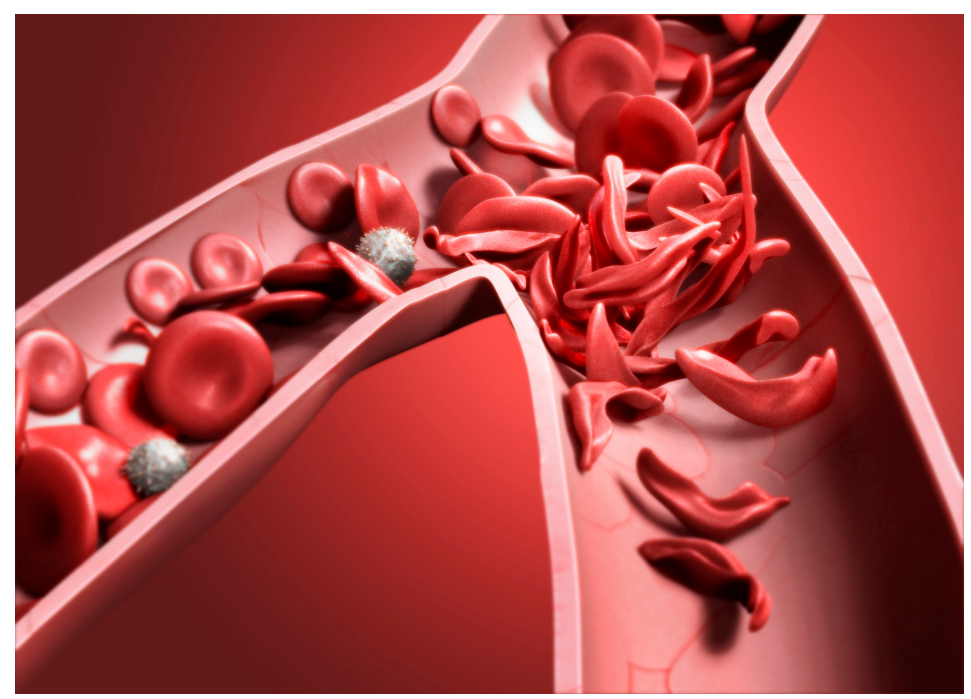

Normale erytrocytter (røde skiver) og erytrocytter påvirket av sigdcelleanemi (halvmåneformet). Sigdceller kan ikke bevege seg gjennom små blodkar like lett som normale celler og kan forårsake blokkeringer. Dette forhindrer oksygen $i$ å nå vevene og kan forårsake alvorlige smerter og organskader. Illustrasjon: Science Photo Library/ NTB Scanpix

Sigdcellesykdom skyldes en medfødt genfeil som påvirker dannelsen av hemoglobin. Sykdommen inngår ikke i nyfødtscreeningen i Norge, men på verdensbasis er det ingen annen diagnose som stilles oftere gjennom screeningprogram for nyfødte. I lavinntektsland er nyfødtscreening basert på tørket blod på filterpapir vanskelig å gjennomføre, fordi det forutsetter at man har logistikk for forsendelse av prøver, laboratorier som kan analysere prøvene og et system for å kommunisere prøveresultatet til de affiserte familiene og lokalt helsepersonell.

I en fersk studie fra Haiti ble en hurtigtest for screening for sigdcellesykdom prøvd ut (1). Studien omfattet over 2100 nyfødte som alle ble testet med isoelektrisk fokusering, som er standardmetoden for nyfødtscreening for sigdcellesykdom. Hurtigtesten ble introdusert etter tre måneder, og to tredjedeler av de nyfødte ble også testet med denne. Der minst én av testene var positive, ble det gjort bekreftende diagnostikk med høypresisjonsvæskekromatografi (HPLC). 
Basert på screeningen ble sigdcellesykdom mistenkt hos 32 nyfødte (1,5\%) og bekreftet hos $18(0,8 \%)$. Hurtigtesten hadde en sensitivitet på $90 \%$ og spesifisitet på $97 \%$, med HPLCdiagnostikken som gullstandard. Med hurtigtesten fikk man mulighet til å formidle den mistenkte diagnosen til mødrene umiddelbart og samtidig henvise barnet for videre oppfølging. Dermed økte andelen som fikk utført bekreftende diagnostikk fra $75 \%$ til 87\%. Barna som fikk diagnosen påvist med hurtigtesten, kom raskere i gang med oppfølgende kontroller og startet tidligere behandling med penicillin og vaksine mot pneumokokker, slik man anbefaler for barn med sigdcellesykdom.

LITTERATUR:

1. Alvarez OA, Hustace T, Voltaire M et al. Newborn screening for sickle cell disease using point-of-care testing in low-income setting. Pediatrics 2019; 144: e20184105. [PubMed][CrossRef]

Publisert: 18. november 2019. Tidsskr Nor Legeforen. DOI: 10.4045/tidsskr.19.0693

(C) Tidsskrift for Den norske legeforening 2020. Lastet ned fra tidsskriftet.no 